\title{
Mikko Keskinen
}

\section{Kirjallisuustiede käänteiden käänteissä. Professoriluento 9.5.2012 Jyväskylän yliopistossa}

Viime vuosikymmenten ihmistieteellisen ja erityisesti kirjallisuustieteellisen keskustelun avainsanoja on käänne. Kirjallisuudentutkimuksessa on tapahtunut tällaisen keskustelun mukaan lingvistinen, diskursiivinen, kognitiivinen, teologinen, jälkikoloniaalinen ja transnationaalinen käänne, vain muutamia mainitakseni. Ihmistieteet ovat kokeneet, näin meille vakuutetaan, milloin kerronnallisen, milloin performatiivisen käänteen. Niiden jälkeen kaikki on kertomusta tai kertomuksen kaltaista - tai sitten kaikki jäsentyy perustavanlaatuisesti esityksen tavoin.

Toisaalta akateemisen lukijan huomio kohdistuu käänneretoriikan mukaan vuoroin tähän, vuoroin tuohon aistiin: Visuaalisen käänteen jälkeen useimmat kirjallisuudentutkijat oletettavasti tarkastelevat tekstejä näköaistimuksiin keskittyen. Tai he kuulostelevat kirjoituksen ääniä akustisen käänteen seurauksena. Makuaistillista käännettä en ole havainnut kirjallisuustieteessä vielä kenenkään ehdottaneen, vaikka sen perusteeksi riittäisi maailmankirjallisuudessa kukkuroittain maisteltavaa pitojen gastronomisia elämyksistä vankileirien jäteruokavalion iljettävyyksiin. Sama pätee hajuaistiin. En ihmettelisi, jos olfaktorisen käänteen tulevat lanseeraajat odottaisivat kirjallisuudentutkijoiden yksissä tuumin kääntävän nenänsä fiktion tuoksuihin, koska aromaattisuus onkin tekstien olennainen mutta laiminlyöty ominaisuus.

Myös tuntoaisti on jäänyt kirjallisuustieteessä vielä liian tuntemattomaksi saadakseen aikaan varsinaista haptista tai taktiilista käännettä, vaikka kosketus onkin ollut vilkkaahkon keskustelun kohteena viime vuosikymmenten ranskalaisessa filosofiassa. Itse tunteet ja tuntemukset ovat kuitenkin nousseet hiljattain uudelleen pintaan kirjallisuudentutkimuksessa. Uuskriitikkojen varoittelut affektioharhasta ovat loitonneet liki kuulumattomiin, ja tunteiden ja tunnekäsitysten laaja kirjo on tullut ajanmukaiseksi tutkimuskohteeksi monitieteisen affektiivisen käänteen myötä.

Toisaalta kääntyilevä kirjallisuustiede ei pyörähtele vain ihmisruumiin ja ihmismielen muodostaman akselin ympäri. Inhimillinen toimija käänteiden napana on kyseenalaistettu, eläimellisen, jälkihumaanin, kyberneettisen ja viimein materialistisen käänteen jälkeen. 


\section{II}

Käänteitä ei ole aina helppo havaita, vaikka niiden lujasti vakuutetaan tapahtuneen, erityisesti konferenssien otsakkeissa, julkaisujen nimissä ja tietenkin hankerahoitushakemusten alkuvirkkeissä. Kyse ei usein ole niinkään vallitsevan asiaintilan kuvauksesta kuin toiveesta kääntää sen painopiste ja kulku toisaalle. Käänneretoriikka näyttäytyy tavan takaa manifestin kaltaisena julistuksena, profetiana tulevasta, pikemminkin kuin jo tapahtuneen muutoksen rekisteröintinä ja vakauttajana. Käännepuhe tarkoittaa siis yleensä toivetta käänteestä eikä oletetun uuden suunnan toteamista.

On kiinnostavaa, miten eri tieteenalat jäsentävät kehityksensä tai historialliset muutoksensa eri tavoin. Luonnontieteissä puhutaan mielellään dramaattisesti kertakaikkisista murroksista, mullistuksista, vallankumouksista ja paradigman vaihdoksista. Kirjallisuustieteessä ja ehkä yleisemminkin ihmistieteissä suositaan mieluummin käänteen retoriikkaa, joka implikoi, että muutos - mahdollisesta äkillisyydestään ja jyrkkyydestään huolimatta - kytkeytyy edeltävään ymmärrykseen asiaintilasta. Ehkä myös siinä mielessä, että paluu aikaisempaan käsitykseen säilyy mahdollisena. Vastaavaa ei voi kuvitella tapahtuvan luonnontieteissä. Tähtitieteessä kääntyminen takaisin maailmankaikkeuden maakeskeiseen malliin ei ole vakavasti otettava vaihtoehto. Mutta kirjallisuustieteessä paluu kirjailijakeskeiseen käsitykseen - herättämällä henkiin kuolleeksi julistettu tekijä ja palauttamalla hänet tekstiuniversumin liikkumattomaksi liikuttajaksi - ei aiheuta suurempaa kummastusta, ei ainakaan koko tiedeyhteisössä. Katkosten ja murtumien sijaan kirjallisuustieteen muutoksissa (eli käänteissä) säilyy mahdollisuus kytköksiin ja jatkuvuuteen. Tätä voidaan kutsua vaikkapa jatkuvuusteesiksi.

Kyse on tietenkin myös tieteenalojen suhteesta fyysiseen todellisuuteen ja sen lainalaisuuksiin. Matkustajina olemme varmastikin huojentuneita, että lentokapteenit eivät yleensä käännähtele kannattamaan fysiikan jo kumottuja teorioita painovoimasta ja kiihtyvyydestä. Lukijoina voimme sen sijaan huoletta suoda kirjallisuuden ammattilaisille vapauden piipahtaa teoreettisessa tai menetelmällisessä menneisyydessä, emmekä juuri hätäänny metodisesta matalalennosta, tulkinnallista turbulenssista tai paradigmaattisesta aikaerorasituksesta. Ainakaan jos perillä matkalaista odottaa edes jossakin määrin kiintoisa luenta.

Joskus lentomatkailijan ja kirjallisuustieteilijän todellisuudet saattavat kohdata käänteentekevällä tavalla. Keväällä 2010 islantilaisen tulivuoren purkaus pysäytti lentoliikenteen Euroopassa ja tuhannet ihmiset jäivät lentoasemille, konferenssihotelleihinsa tai kotiinsa, voimatta matkustaa päämääränsä. Tätä ilmiötä alettiin pian kutsua "vulkaaniseksi käänteeksi”. Sen uskottiin tuottavan "uudenlaista ajattelua", koska "kiireisten eurooppalaisten pakkopysähtymiset poikivat oivalluksia, kohtaamisia, vieraanvaraisuutta ja luovuutta" (Pohjola 2011, A8). Tuhkapilven maankamaralle vangitsemilla kirjalli- 
suustieteilijöillä oli siis kerrankin aikaa käännellä niteittensä sivuja, mutta myös kääntyä muiden ihmisten puoleen. Tällainen käänne oli siis todellinen ja käytännöllinen, vaikkakaan ei sen pysyvämpi olotila kuin muutokset teoriarintamalla. Tuhkapilven hälventymistä seurasi nopea kääntyminen normaaliin kiireeseen ja tavanomaiseen ajatteluun.

\section{III}

Kirjallisuustieteen viehtymys käänteisiin liittyy kiintoisasti koko oppialan (perinteisesti) keskeiseen tutkimuskohteeseen: sanataiteeseen ja sen erityispiirteisiin. Kirjallisuuden kieltä luonnehtii olennaisesti sanojen käyttäminen kirjaimellisesta merkityksestä poikkeavalla tavalla. Kyse on tietenkin troopeista. Termi trooppi juontuu kreikan sanasta tropos, joka merkitsee muun muassa 'käännettä' ja 'mutkaa'. Kirjallisuus itse on siis olennaisella tavalla käänteen tekevää, kääntyilevää, tunnusmerkittömästä, annetusta ja tutusta tuonnemmas pyrkivää, kuitenkin niin että yhdysside, ohuenakin, luonnolliseen kieleen säilyy.

Voisimme soveltaa tätä tropologista periaatetta, vaikkapa lingvistisen käänteen hengessä, itse käänne-sanaan. Ei ole itsestään selvää, että käänne tarkoittaa kirjallisuustieteen diskurssissa vain 'muutosta', 'murrosta' tai 'käännekohtaa' (saati 'kriisiä', 'epookkia', 'oikaisua', 'parannusta' tahi 'uudistusta'). Toki nuo kolme ensiksi mainittua ovat käänteen ilmeisimmät mielet ja vaikkapa kerronnallisen käänteen käyttöyhteydessä juuri tarkoitetut merkitykset. Mutta trooppeja kaunokirjallisuudessa lukiessamme olemme tottuneet etsimään myös harvinaisempia mieliä sanoille ja katsomaan, miten ne kenties rikastavat tekstin tulkintaa.

Käänne-sanalla on runsaasti synonyymejä, eli sillä voi olla lukuisia merkityksiä eri käyttöyhteyksissä. Käänne voi tarkoittaa tekstiilien maailmassa muun muassa 'paltetta', eli 'päärmettä, taitetta ja laskosta'. Toisaalta käänne tarkoittaa merenkulun yhteydessä 'pallea', eli ’pilssivettä' (aluksen pohjalle päässyttä vettä, johon sekoittuu öljyä). Tässä mielessä käänne on jäänne. En mene tarkemmin näiden merkitysten kirjallisuustieteelliseen käyttökelpoisuuteen, vaan jätän sen teidän huoleksenne. Tekstiilin tai nesteiden suhde tekstiin ei ole tuiki tuntematon tapa käsitteellistää kirjallisuuden olennaisiksi ymmärrettyjä ominaisuuksia, kuten vaikkapa Roland Barthesin ja Julia Kristevan lukijat muistanevat.

Käänteen merkityksiä voidaan jäsentää kiintoisasti myös tilan kannalta. Ilmeisin tapa ymmärtää käänne suhteessa tilaan on käsittää se muutoksena horisontaalisessa etenemisessä, eli yksinkertaisesti ohjausliikkeenä matkanteossa. Tämän jäsennyksen mukaisesti kirjallisuustiede purjehtii kuin laiva, jonka ruoria kääntelee milloin narratologi, milloin kulttuurintutkija saadakseen kurssin haluamakseen (ja aikaisemmat suuntimavirheet korjausliikkeellä oikaistuksi).

Ruorimieheksi pääsystä kamppaillaan kiivaasti, ja lokikirja kertoo, että laivan kurs- 
sia muutellaan tiheään tahtiin. Aluksen reitti näyttää kuitenkin melko suoraviivaiselta merikartasta katsottuna. Miten tämä on mahdollista? Paristakin syystä. Ensinnäkin jatkuvat korjausliikkeet kumoavat toisensa, eli käänteet eri suuntiin pitävät kurssin kokonaisuudessaan otettuna vakaana. Toisaalta kirjallisuudentutkimus (instituutiona) on raskasliikkeinen alus, jonka kääntäminen kokonaan vie kauemmin kuin seuraavaan kurssinmuutokseen on aikaa. Alus siis näyttää kyntävän vakaasti eteenpäin - kannella puhkeavista pienimuotoisista kapinoista huolimatta.

Mutta käänne voi tapahtua myös vertikaalisesti, syvemmälle ja tiukemmalle porautuen tai laajemmalle ja höllemmälle kiertyen. Siis niin kuin ruuvia vääntäessä tapahtuu. Tällä tavoin ymmärrettynä käänne liittyy ehkä tekstisuhteeseen. Eli käännytäänkö hermeneuttisella jengalla lähemmäs tekstin oletettua ydintä vai kiinnitytäänkö mieluummin ympäröiviin ei-tekstuaalisiin alueisiin, kuten neurotiede, nykyiskansain vaiheet tai sukupuolipolitiikka.

En jatka näitä analogioita pitemmälle. Muuten kuin toteamalla, että laiva ja ruuvi ovat eri tason ilmiöitä; toinen liittyy kirjallisuustieteeseen instituutiona, toinen tutkimuksen tekemiseen ja tulkinnan taustaoletuksiin. Kirjallisuustieteen juonenkäänteet ovat ennustettavia, mutta toteutuessaan oudon yllättäviä. Ennustan olfaktorisen käänteen joskus tapahtuvan (tai pikemminkin väitettävän tapahtuneeksi), mutta tämä ei poista jonkinasteista hämmästystä sen käydessä toteen. Äimistys voi tosin johtua paitsi tutkimussuuntauksen mahdollisista perusteluista myös itse kielen performatiivisesta voimasta à la Andy McCoy. Juuri käänteellä spekulointi, ironisestikin, voi saada sen aikaan.

\section{IV}

Käänne luonnehtii siis kirjallisuutta ja kirjallisuudentutkimusta monella tasolla ja monessa mielessä. On jopa esitetty, että tulkitsevassa diskurssissa ajatus etenee enemmän tai vähemmän ennustamattomin käännöksin. Samalla käänne kuvaa liikettä, jolla yksi koulukunta seuraa toista kirjallisuustieteen historiassa. Kirjallisuudentutkimuksen eteneminen voidaan ymmärtää sarjana kannoillaan (tai kannaltaan) kääntymisiä, joita säestää vakuuttelu suunnanvaihdosten tärkeydestä, jopa välttämättömyydestä. Näin liike jatkuu, niin kuin siitä käytävä puhekin - vastaisesti tai myötäisesti.

Käänne on niin tyypillistä viime vuosikymmenten kirjallisuustieteen retoriikassa, että voisimme jopa puhua käänteellisestä käänteestä kirjallisuudentutkimuksessa. Tällä uudismuodosteella ei kenties ole arvoa tekstintulkinnan käytännössä, se ei siis jaksane sanottavasti kääntää tieteenalan kulkua. Mutta metatason käsitteenä sillä saattaisi olla oma roolinsa, vaikkapa sitten ironinen, kirjallisuustieteen itseymmärryksen kannalta. Käänteellisen käänteen lanseerauksen jälkeen käännepuhe voi näyttää paljaammin tropologiselta ja saada meidät miettimään, millaiset olisivat muutoksen ehdot, ominais- 
piirteet, merkitykset ja vaikutukset. Milloin käänne on mahdollinen tai todennäköinen? Mikä käännettä luonnehtii ja mikä erottaa sen vaikkapa suuntauksen sisäisestä hienosäädöstä? Onko käännepuhe konstatiivista vai performatiivista, toteavaa vai muuttavaa? Kohdistuuko käänne tukemaan vai vastustamaan? Vai onko niin, että ihminen ikuisesti kuulee korvassaan yksitoikkoisen äänen juuri siitä rattaasta, jota hän itse pyörittää?

Näistä kaikista, siis käänteen ehdoista, ominaispiirteistä, merkityksistä ja vaikutuksista saattaa kertoa (tai kysyä, ilman kysymysmerkkiä) Mirkka Rekolan runo "Akselin napa" kokoelmasta Anna päivän olla kaikki (1968):

Akselin napa on hyvin voideltu, siitä ei kuulu mitään, mutta kaikki mihin pyörä ottaa, kitisee parahtaa.

Kuinka juuri sillä on pyörän ääni.

(Rekola 1981/1968, 185.)

\section{Lähteet}

pohjola, Johanna 20II: Vulkaanisen käänteen jälkeen. Helsingin Sanomat 31.10.2011, A8.

REKOLA, MIRKKA I98I/I968: Akselin napa. Runot 1954-1978. Helsinki: WSOY, 185. 